\title{
Association between cellular immune response and spleen weight in mice with hepatocellular carcinoma
}

\author{
WEI JIANG ${ }^{1,2}$, YU LI ${ }^{2,3}$, SHUQUN ZHANG ${ }^{1}$, GUANGYAO KONG $^{2}$ and ZONGFANG LI ${ }^{1,2,4}$ \\ ${ }^{1}$ Department of Oncology, ${ }^{2}$ National and Local Joint Engineering Research Center of Biodiagnosis and Biotherapy, \\ ${ }^{3}$ Department of Thoracic Surgery, The Second Affiliated Hospital of Xi'an Jiaotong University; \\ ${ }^{4}$ Key Laboratory of Environment and Disease-Related Gene Ministry of Education, \\ Xi'an Jiaotong University, Xi'an, Shaanxi 710004, P.R. China
}

Received October 19, 2020; Accepted May 24, 2021

DOI: 10.3892/ol.2021.12886

\begin{abstract}
The spleen is an important site for extramedullary hematopoiesis and tumor immunotolerance. Spleen weight varies with tumor progression and may be a predictor of tumor recurrence. However, to the best of our knowledge, the association between spleen weight and tumor progression remains unclear. The present study revealed a novel role for the spleen in predicting the cellular immune response in tumor-bearing mice. A murine H22 subcutaneous hepatoma model was established. The spleen weight and tumor weight were measured. The proportion of immune cells in peripheral blood and spleen were detected by flow cytometry. The results demonstrated that the spleen weight of tumor-bearing mice at day 21 was higher than that of the controls. In addition, spleen weight was identified to be positively correlated with tumor weight. The percentages of $\mathrm{CD}^{+}$and $\mathrm{CD} 8^{+} \mathrm{T}$ lymphocytes in the spleen were decreased at day 21 after tumor cell inoculation, while those of monocytic-like myeloid-derived suppressor cells (M-MDSCs) and CD11b $\mathrm{b}^{+} / 80^{+}$macrophages were increased at day 21 after tumor cell inoculation. Similarly, the percentage of polymorphonuclear-like MDSCs (PMN-MDSCs) in the spleen of tumor-bearing mice was increased at days 7, 14 and 21 after tumor cell inoculation. Notably, spleen weight was negatively correlated with the percentages of $\mathrm{CD} 4^{+}$and $\mathrm{CD} 8^{+}$ $\mathrm{T}$ lymphocytes in the spleen, although spleen and tumor weight were positively correlated with the percentages of M-MDSCs and PMN-MDSCs in the spleen. Similarly, the percentages of $\mathrm{CD} 8^{+} \mathrm{T}$ lymphocytes in the peripheral blood were decreased, and programmed cell death protein 1 expression on $\mathrm{CD} 8^{+} \mathrm{T}$ lymphocytes was increased at day 21 after tumor
\end{abstract}

Correspondence to: Professor Zongfang Li, National and Local Joint Engineering Research Center of Biodiagnosis and Biotherapy, The Second Affiliated Hospital of Xi'an Jiaotong University, 157 The West 5th Road, Xi'an, Shaanxi 710004, P.R. China E-mail:1zf2568@mail.xjtu.edu.cn

Key words: spleen, hepatocellular carcinoma, myeloid cells, immune tolerance cell inoculation. Furthermore, the percentages of M-MDSCs were increased at day 21 and PMN-MDSCs in the peripheral blood were increased at days 7,14 and 21 after tumor cell inoculation. Additionally, spleen and tumor weight were also positively correlated with the percentages of M-MDSC and PMN-MDSCs in the peripheral blood of tumor-bearing mice. Collectively, the findings of the present study suggested that spleen weight may be a predictor of tumor prognosis, since it was directly correlated with tumor weight and the percentages of M-MDSC and PMN-MDSCs in tumor-bearing mice.

\section{Introduction}

Tumors escape immune surveillance by developing an immunosuppressive microenvironment that induces immune tolerance (1). This tumor microenvironment contains various immunosuppressive cells, including tumor-associated macrophages (TAMs), myeloid-derived suppressor cells (MDSCs) and tumor-associated neutrophils (TANs), which contribute to immune tolerance and tumor progression (2-4). Tumor immune tolerance is characterized by tumor myelopoiesis (1), which is not only characterized by the accumulation of myeloid precursors, but is also associated with defective cellular differentiation that results in the accumulation and persistence of immunosuppressive myeloid cells (5). These myeloid cells promote tumor progression by regulating the antitumor immune activity of T lymphocytes, natural killer T (NKT) cells, natural killer (NK) cells, dendritic cells (DCs) and various other cell types (6). Previous studies have demonstrated that the spleen is an important site of extramedullary hematopoiesis, which generates immunosuppressive myeloid cells in tumor-bearing mice $(7,8)$. Therefore, investigation of the association between the spleen and cancer immunology is crucial to an improved understanding of tumor immune tolerance.

The role of splenectomy in tumor behavior has recently received increasing attention (9). Clinical studies have demonstrated that traumatic splenectomy in healthy individuals can increase the risk of cancer, while splenectomy in patients with post-hepatitis cirrhosis is associated with a reduced risk of hepatocellular carcinoma $(10,11)$. Previous studies have demonstrated that the spleen is an origin of MDSCs in tumor-bearing mice $(7,12)$. Additionally, our previous studies indicated that 
a large number of myeloid cells accumulate in the spleens of tumor-bearing mice $(13,14)$, and the spleen has been reported as a site of tumor immune tolerance (1). As such, an increasing number of studies have reported the inhibitory effects of splenectomy on tumor progression $(9,15,16)$. However, to the best of our knowledge, the relevance of spleen weight and volume in tumor progression remains unclear. Although a decrease in spleen volume has been observed in patients with locally advanced non-small cell lung cancer receiving chemo-radiotherapy (17), the association between spleen weight and tumor weight also remains to be clarified. Specifically, the spleen is an origin of myeloid cells $(5,7)$; however, little is known of the association between spleen weight and the immune response in tumor-bearing mice. Clarifying the relevance of spleen weight in tumor progression may provide a novel strategy for anticancer therapy. In the present study, dynamic changes in the percentages of immune cells in the spleen and peripheral blood, as well as the association between spleen weight and immune cells in the spleen and peripheral blood of tumor-bearing mice, were evaluated.

\section{Materials and methods}

Cell line and cell culture. H22 murine hepatoma cells were purchased from China Center for Type Culture Collection (cat. no. GDC0091). The cells were cultured in RPMI-1640 (HyClone; Cytiva) supplemented with 10\% FBS (Gibco; Thermo Fisher Scientific, Inc.) and $1 \%$ penicillin/streptomycin, and maintained at $37^{\circ} \mathrm{C}$ with $5 \% \mathrm{CO}_{2}$ in a humidified atmosphere.

Mice. A total of 36 male C57BL/6 mice (age, 6-8 weeks; weight, $23.9 \pm 1.9 \mathrm{~g}$ ) were purchased from the Experimental Animal Center of Xi'an Jiaotong University (Xi'an, China). All animals were housed at the animal facility under specific pathogen-free conditions, at $26^{\circ} \mathrm{C}$ with a relative humidity of $50 \%$, with a 12-h light/dark cycle and free access to food and water. The study was approved by the Ethics Committee of Xi'an Jiaotong University College of Medicine (Xi'an, China).

Antibodies. The following antibodies were purchased from BioLegend, Inc.: FITC anti-CD3 (dilution, 1:80; cat. no. 100204), phycoerythrin (PE) anti-CD4 (dilution, 1:80; cat. no. 100407), allophycocyanin (APC) anti-CD8a (dilution, 1:80; cat. no. 100712), Brilliant Violet $421^{\mathrm{TM}}$ anti-CD279 [programmed cell death protein 1 (PD1); dilution, 1:50; cat. no. 135218], FITC anti-CD11c (dilution, 1:200; cat. no. 117306), purified anti-CD16/32 (dilution, 1:80; cat. no. 101302), APC anti-CD11b (dilution, 1:80; cat. no. 101212), APC anti-adhesion G protein-coupled receptor E1 (F4/80; dilution, 1:80; cat. no. 123116), FITC anti- lymphocyte antigen 6 (Ly6)G (dilution, 1:400; cat. no. 127606), PE/Cy7 anti-CD11b (dilution, 1:160; cat. no. 101216) and PE anti-Ly6C (dilution, 1:80; cat. no. 128008). The following antibodies were purchased from eBioscience; Thermo Fisher Scientific, Inc.: PE anti-major histocompatibility complex (MHC)II (dilution, 1:500; cat. no. 12-5321-81) and peridinin-chlorophyll-protein-Cyanine5.5 anti-natural killer 1.1 (dilution, 1:60; NK1.1; cat. no. 45-5941-82). PE/Cy7 anti-CD11b and APC anti-F4/80 were used for macrophages. APC anti-CD11b, FITC anti-Ly6G and PE anti-Ly6C were used for MDSCs. The biomarkers used to identify immune cells are shown in Table I.

Animal model. Tumor models were performed as previously described (18). The entire duration of the experiment was 21 days. Briefly, $\mathrm{H} 22$ cells (5x105 cells in $100 \mu$ l normal saline) were subcutaneously injected into the right flanks of male C57BL/6 mice. Control mice were not injected with $\mathrm{H} 22$ cells. The spleen weight was recorded at days 7 (4 control mice and 6 tumor-bearing mice), 14 (5 control mice and 8 tumor-bearing mice) and 21 (5 control mice and 8 tumor-bearing mice), and the tumor weight was recorded at days 14 (5 control mice and 8 tumor-bearing mice) and 21 (5 control mice and 8 tumor-bearing mice) post-tumor cell injection. The maximum tumor diameter was $1.35 \mathrm{~cm}$. Spleen and peripheral blood samples were also collected and immediately used for flow cytometric analysis at 7,14 and 21 days after injection. Mouse health and behavior, including exercise, diet and weight of mice, were monitored every day. The mice were anesthetized using an intraperitoneal injection of sodium pentobarbital (50 $\mathrm{mg} / \mathrm{kg}$; Merck KGaA) and subsequently sacrificed by cervical dislocation at 7, 14 and 21 days after tumor cell injection.

Generation of single-cell suspensions. Single-cell suspensions were generated as previously described $(18,19)$. Briefly, $\sim 1 \mathrm{ml}$ peripheral blood was collected from each mouse into EDTA-coated tubes and diluted 1:5 in $\mathrm{NH}_{4} \mathrm{Cl}$ lysing buffer $\left(0.16 \mathrm{M} \mathrm{NH}_{4} \mathrm{Cl}, 10 \mathrm{mM} \mathrm{KHCO}_{3}, 0.13 \mathrm{mM}\right.$ EDTA, $\mathrm{pH}$ 7.2) for $5 \mathrm{~min}$ on ice. The samples were then centrifuged at $350 \mathrm{xg}$ for $5 \mathrm{~min}$ at $4^{\circ} \mathrm{C}$. The pelleted cells were washed twice with PBS/5\% FBS buffer (Beyotime Institute of Biotechnology), in which they were then resuspended and quantified $\left(1 \times 10^{6}\right.$ cells $\left./ \mathrm{ml}\right)$. To obtain single-cell suspensions, the spleen tissues were resuspended in ice-cold PBS/5\% FBS buffer and disrupted mechanically. Similarly, red blood cells were lysed by adding $5 \mathrm{ml} \mathrm{NH}_{4} \mathrm{Cl}$ lysing buffer for $5 \mathrm{~min}$ on ice, followed by centrifugation at $350 \mathrm{xg}$ for $5 \mathrm{~min}$ at $4^{\circ} \mathrm{C}$. The pelleted cells were then washed twice and resuspended (both in PBS/5\% FBS buffer), and the concentration was adjusted to $1 \times 10^{6}$ cells $/ \mathrm{ml}$.

Flow cytometric analysis. Flow cytometry was performed as previously described $(19,20)$. The single-cell suspensions were collected in tubes and blocked with a CD16/32 antibody for $15 \mathrm{~min}$, followed by incubation with the appropriate antibodies for $30 \mathrm{~min}$ at $4^{\circ} \mathrm{C}$. Data were acquired using the FACSCanto II flow cytometer iva 7.0 software (BD Biosciences). FlowJo software 7.6.1 (Tree Star, Inc.) was used for data analysis.

Calculation of spleen index (SI). The SI was calculated according to the following formula: $\mathrm{SI}=$ spleen weight $(\mathrm{g}) /$ body weight (g).

Statistical analysis. All data are presented as the mean \pm standard error of the mean. All experiments were repeated three times. Data were analyzed with SPSS 17.0 software (SPSS, Inc.). One-way ANOVA followed by Bonferroni's test was used to compare the means among multiple samples. Pearson's correlation analysis was used for correlation analysis and linear regression analysis was performed to confirm the 

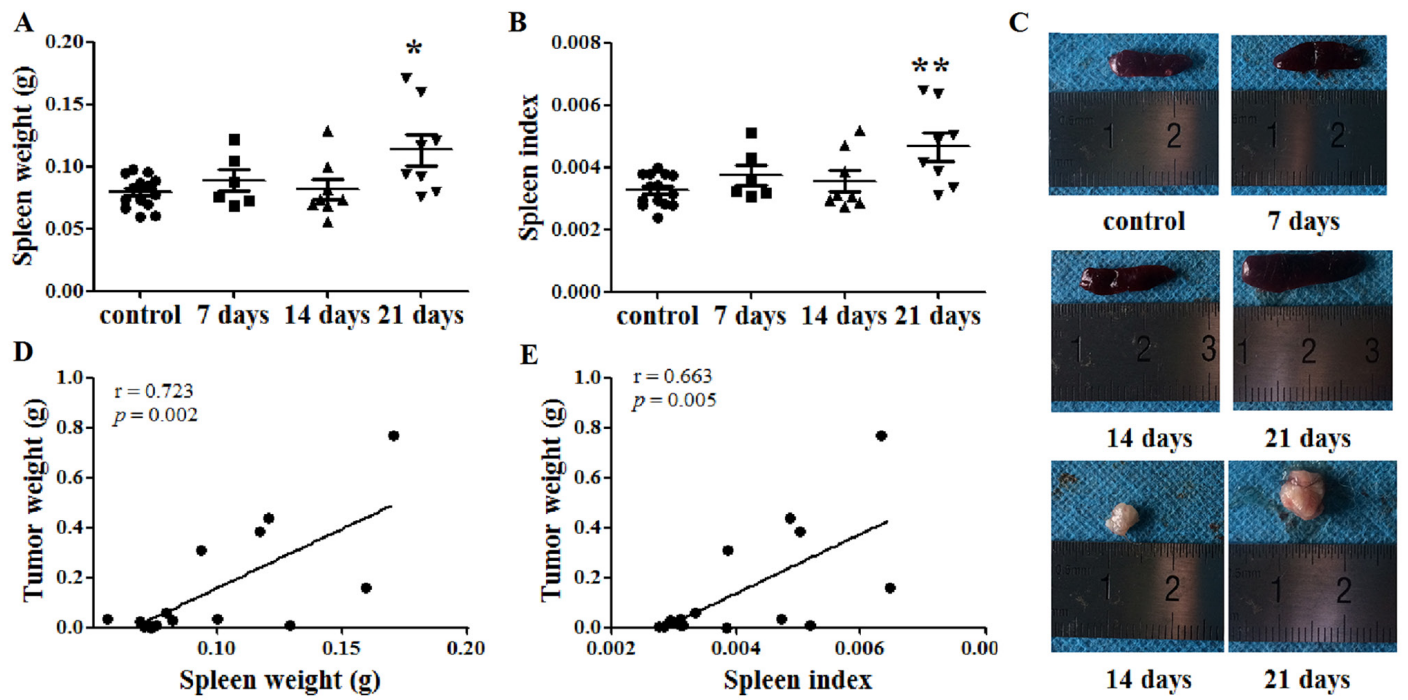

Figure 1. Spleen weight is positively correlated with tumor weight. (A) Spleen weight and (B) spleen index of tumor-bearing mice at day 21 after tumor cell inoculation were greater than those of the control group. (C) Representative spleen and tumor images. (D) Spleen weight and (E) spleen index were positively correlated with tumor weight. ${ }^{*} \mathrm{P}<0.05$ and ${ }^{* *} \mathrm{P}<0.01$ vs. control.

Table I. Biomarkers of immune cells.

\begin{tabular}{|c|c|}
\hline Immune cells & Biomarkers \\
\hline $\mathrm{CD}^{+} \mathrm{T}$ lymphocytes & $\mathrm{CD}^{+}$ \\
\hline $\mathrm{CD}^{+} \mathrm{T}$ lymphocytes & $\mathrm{CD}^{+}$ \\
\hline Myeloid cells & $\mathrm{CD}_{11} \mathrm{~b}^{+}$ \\
\hline M-MDSCs & CD11b+Ly6C ${ }^{\text {hi }}$ Ly6G $^{-}$ \\
\hline Macrophages & $\mathrm{CD} 11 \mathrm{~b}^{+} \mathrm{F} 4 / 80^{+}$ \\
\hline PMN-MDSCs & CD11b ${ }^{+}$Ly6C ${ }^{\text {low }}$ Ly6G $^{+}$ \\
\hline DCs & $\mathrm{CD} 11 \mathrm{c}^{+} \mathrm{MHCII}^{+}$ \\
\hline NK & CD3-NK1.1 ${ }^{+}$ \\
\hline NKT & $\mathrm{CD}^{+} \mathrm{NK} 1.1^{+}$ \\
\hline
\end{tabular}

DCs, dendritic cells; F4/80, adhesion G protein-coupled receptor E1; hi, high; Ly6, lymphocyte antigen 6; MHC, major histocompatibility complex; M-MDSCs, monocytic-like myeloid-derived suppressor cells; NK, natural killer cells; NK1.1, natural killer 1.1; NKT, natural killer T cells; PMN-MDSCs, polymorphonuclear-like myeloid-derived suppressor cells.

association. $\mathrm{P}<0.05$ was considered to indicate a statistically significant difference.

\section{Results}

Spleen weight is positively correlated with tumor weight. The spleen weight of each mouse was recorded, and the SI was calculated at days 7,14 and 21 after tumor cell injection. At day 21 , the spleen weights of the tumor-bearing mice were significantly increased compared with those of the control mice $(\mathrm{P}<0.05$; Fig. 1A and C). Similarly, the SI of the tumor-bearing mice was increased compared with that of the control mice at 21 days after tumor cell inoculation $(\mathrm{P}<0.01$; Fig. 1B). Additionally, the tumor weight was recorded at days 14 and 21. Subsequently, the correlation between spleen and tumor weight was investigated. Notably, both spleen weight and SI were identified to be positively correlated with tumor weight, with Pearson's r values of $0.723(\mathrm{P}=0.002$; Fig. 1D) and 0.663 $(\mathrm{P}=0.005$; Fig. 1E), respectively.

Immune cell balance is disrupted in the spleens of tumor-bearing mice. Flow cytometry was used to investigate changes in immune cell populations in the spleens of tumor-bearing mice. The results indicated that at day 21 after tumor cell inoculation, the percentages of $\mathrm{CD}^{+}{ }^{+}$splenic $\mathrm{T}$ lymphocytes were lower than those of the control group $(\mathrm{P}<0.01$; Figs. 2A and S1A). Similarly, the percentages of $\mathrm{CD}^{+}$splenic $\mathrm{T}$ lymphocytes were decreased at days 14 and 21 post-injection compared with those in the normal control mice $(\mathrm{P}<0.05$; Figs. 2B and S1A). As an immunosuppressive marker of T lymphocytes, PD1 expression on T lymphocytes was also investigated in tumor-bearing mice (3). The results indicated no significant differences in the expression levels of PD1 on $\mathrm{CD}^{+}{ }^{+}$(P>0.05; Figs. $2 \mathrm{C}$ and $\left.\mathrm{S} 1 \mathrm{~B}\right)$ and $\mathrm{CD}^{+} \mathrm{T}$ lymphocytes ( $\mathrm{P}>0.05$; Figs. 2D and $\mathrm{S} 1 \mathrm{C}$ ) between the tumor-bearing and control mice.

As predicted, the percentage of $\mathrm{CD} 11 \mathrm{~b}^{+}$splenic myeloid cells at 21 days post-inoculation was notably higher than that of the control group $(\mathrm{P}<0.01$; Fig. $2 \mathrm{E})$. Since myeloid cells include MDSCs and macrophages $(5,6)$, flow cytometry was used to evaluate alterations in the levels of these cell subgroups. Monocytic-like MDSCs (M-MDSCs) can be defined as CD11b+Ly6C-high (Ly6C $\left.{ }^{\text {hi }}\right)$ Ly6G $^{-}$and polymorphonuclear-like MDSCs (PMN-MDSCs) can be defined as CD11b ${ }^{+}$Ly6C $C^{\text {low }} \mathrm{Ly}_{6 G^{+}}(21)$. The percentages of CD11b ${ }^{+}$Ly6C ${ }^{\text {hi }}{ }^{2 y 6 G}{ }^{-}$M-MDSCs $(\mathrm{P}<0.05$; Fig. $2 \mathrm{~F}$ and L) and $\mathrm{CD}_{11} \mathrm{~b}^{+} \mathrm{F} 4 / 80^{+}$splenic macrophages $(\mathrm{P}<0.01$; Figs. $2 \mathrm{G}$ and $\mathrm{S} 1 \mathrm{D})$ in the spleens of tumor-bearing mice were higher than those in the control mice at 21 days post-inoculation. Similarly, the percentage of $\mathrm{CD}_{11} \mathrm{~b}^{+} \mathrm{Ly} 6 \mathrm{C}^{\text {low }} \mathrm{Ly} 6 \mathrm{G}^{+}$PMN-MDSCs in the spleen of tumor-bearing mice was increased at days $7(\mathrm{P}<0.05$; Fig. 2H), $14(\mathrm{P}<0.05$; Fig. $2 \mathrm{H})$ and $21(\mathrm{P}<0.01$; Fig. $2 \mathrm{H}$ and $\mathrm{L})$ compared with the control mice. 


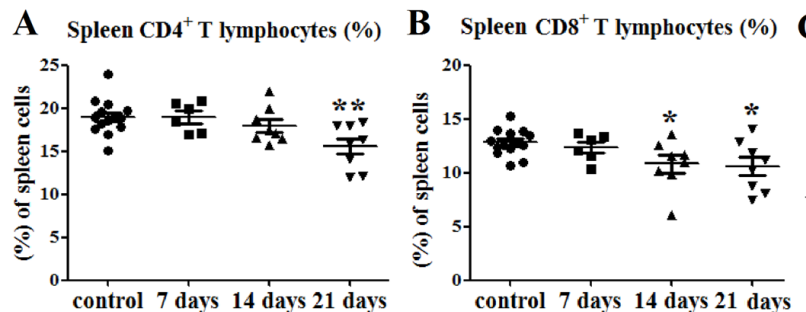

E Spleen CD11b ${ }^{+}$myeliod cells (\%)
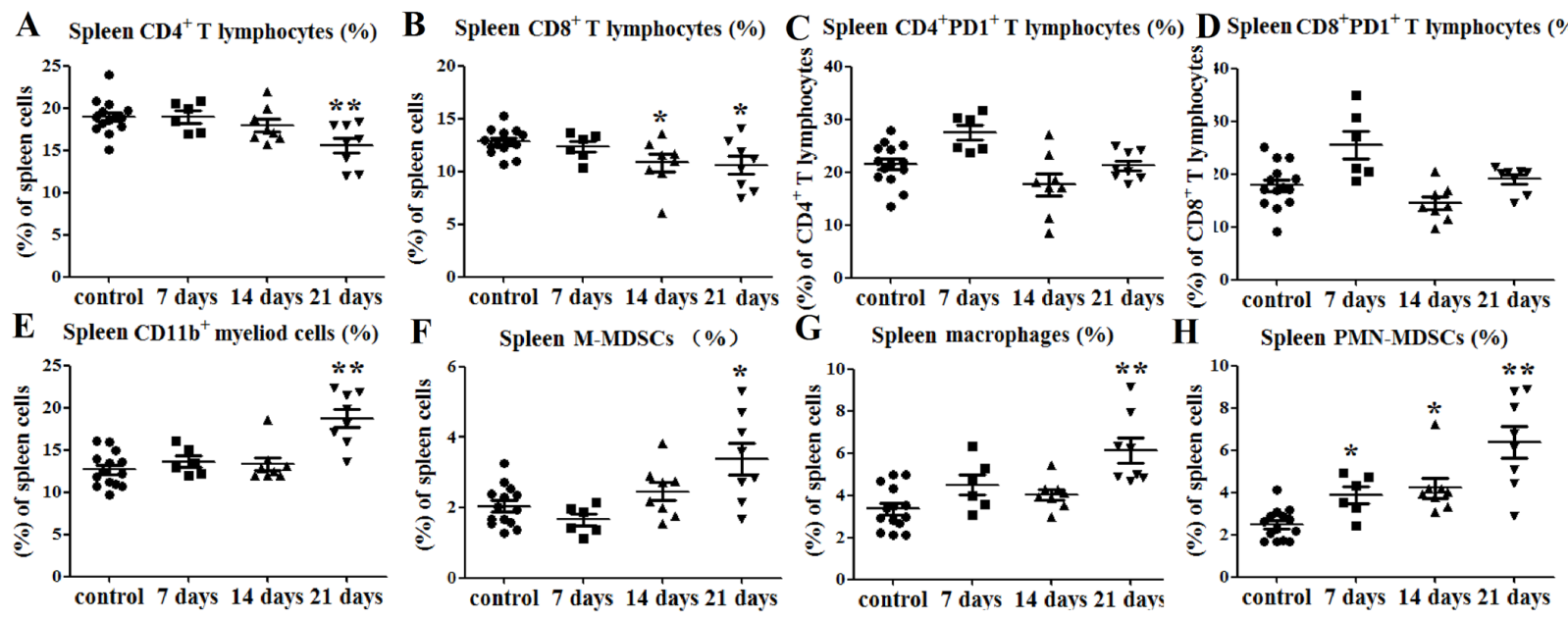

H Spleen PMN-MDSCs (\%)
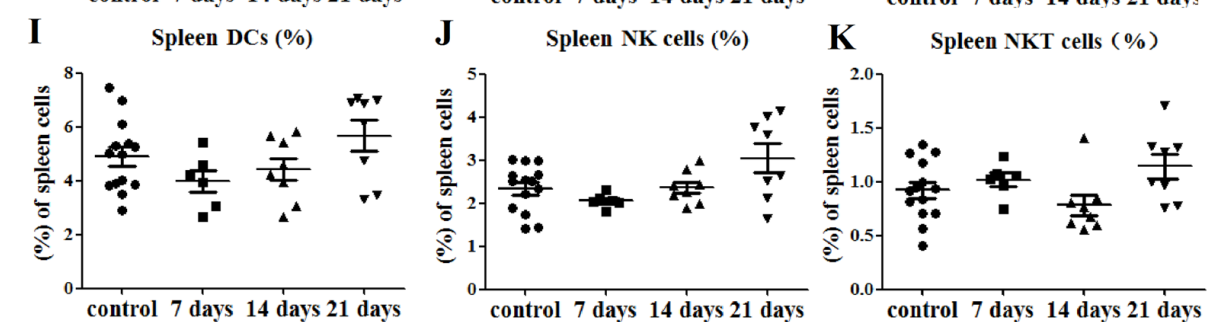

L
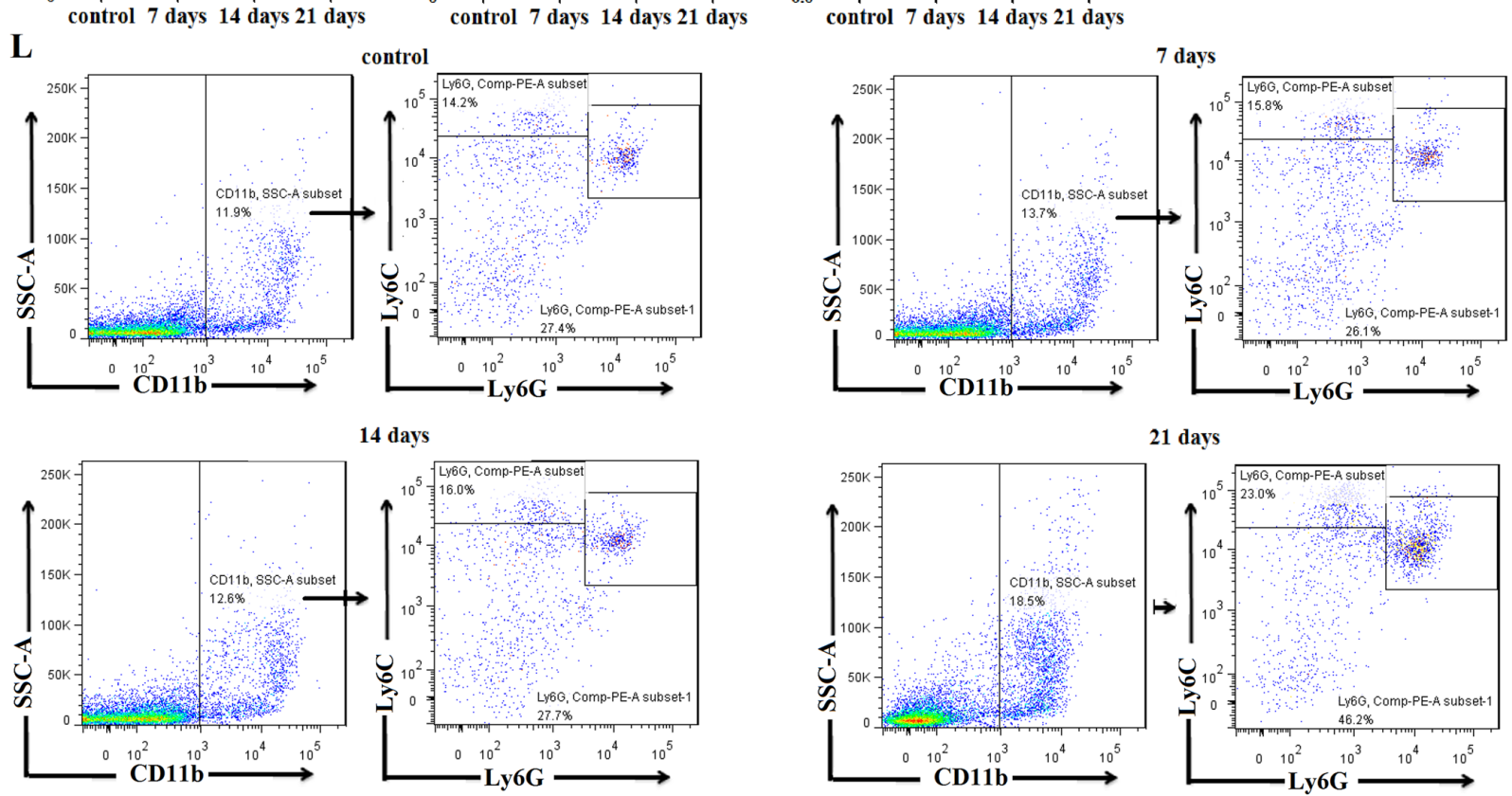

Figure 2. Immune cell balance is disrupted in the spleens of tumor-bearing mice. (A) Percentages of $\mathrm{CD}^{+}$splenic T lymphocytes were decreased at 21 days post-tumor cell inoculation. (B) Percentages of $\mathrm{CD}^{+}$splenic T lymphocytes were decreased at 14 and 21 days post-tumor cell inoculation. No significant differences in PD1 expression on (C) $\mathrm{CD}^{+}$and (D) $\mathrm{CD}^{+} \mathrm{T}$ lymphocytes were observed between tumor-bearing and control mice. Percentages of (E) CD11b ${ }^{+}$splenic myeloid cells, (F) CD11b ${ }^{+}$Ly6 $\mathrm{C}^{\text {hi}}$ Ly6G- M-MDSCs and (G) $\mathrm{CD} 11 \mathrm{~b}^{+} \mathrm{F} 4 / 80^{+}$splenic macrophages (among total cells) were increased at 21 days after tumor cell inoculation. (H) Percentages of CD11b ${ }^{+} \mathrm{Ly} 6 \mathrm{C}^{\mathrm{low}} \mathrm{Ly} 6 \mathrm{G}^{+}$PMN-MDSCs in the spleens (among total cells) of tumor-bearing mice were increased at 7,14 and 21 days after tumor cell injection. There were no significant differences in the percentages of (I) CD11 ${ }^{+} \mathrm{MHCII}^{+} \mathrm{DCs}$, (J) CD3 ${ }^{-} \mathrm{NK} 1.1^{+} \mathrm{NK}$ cells and (K) CD3 ${ }^{+} \mathrm{NK} 1.1^{+}$ NKT cells between the tumor-bearing mice and control mice. (L) Representative flow cytometry dot plots of splenic MDSCs. ${ }^{*} \mathrm{P}<0.05$ and ${ }^{* *} \mathrm{P}<0.01 \mathrm{vs}$. control. F4/80, adhesion G protein-coupled receptor E1; hi, high; Ly6, lymphocyte antigen 6; MDSC, myeloid-derived suppressor cell; MHC, major histocompatibility complex; NK1.1, natural killer 1.1; NKT, natural killer T; M-MDSCs, monocytic-like myeloid-derived suppressor cells; PMN-MDSCs, polymorphonuclear-like myeloid-derived suppressor cells; DCs, dendritic cells; PD1, programmed cell death protein 1; SSC-A, side scatter area.

The percentages of CD11 ${ }^{+} \mathrm{MHCII}{ }^{+} \mathrm{DCs}, \mathrm{CD} 3 \mathrm{NK}^{-} 1^{+} \mathrm{NK}$ and $\mathrm{CD} 3^{+} \mathrm{NK} 1.1^{+} \mathrm{NKT}$ cells in the spleens of tumor-bearing mice were also determined. The results indicated no significant differences in the percentages of DCs $(\mathrm{P}>0.05$; Figs. 2I and S1E), NK cells ( $\mathrm{P}>0.05$; Figs. $2 \mathrm{~J}$ and $\mathrm{S} 1 \mathrm{~F})$ and NKT cells $(\mathrm{P}>0.05$; Figs. $2 \mathrm{~K}$ and $\mathrm{S} 1 \mathrm{~F})$ between the tumor-bearing and control mice. Therefore, these data indicated that the percentages of $\mathrm{T}$ lymphocytes were decreased, while those of myeloid cells were increased in the spleens of tumor-bearing mice compared with those of control mice.

Spleen weight is correlated with cellular immune response in the tumor-bearing mouse spleen. Therefore, the potential correlations between spleen weight or tumor weight and the 

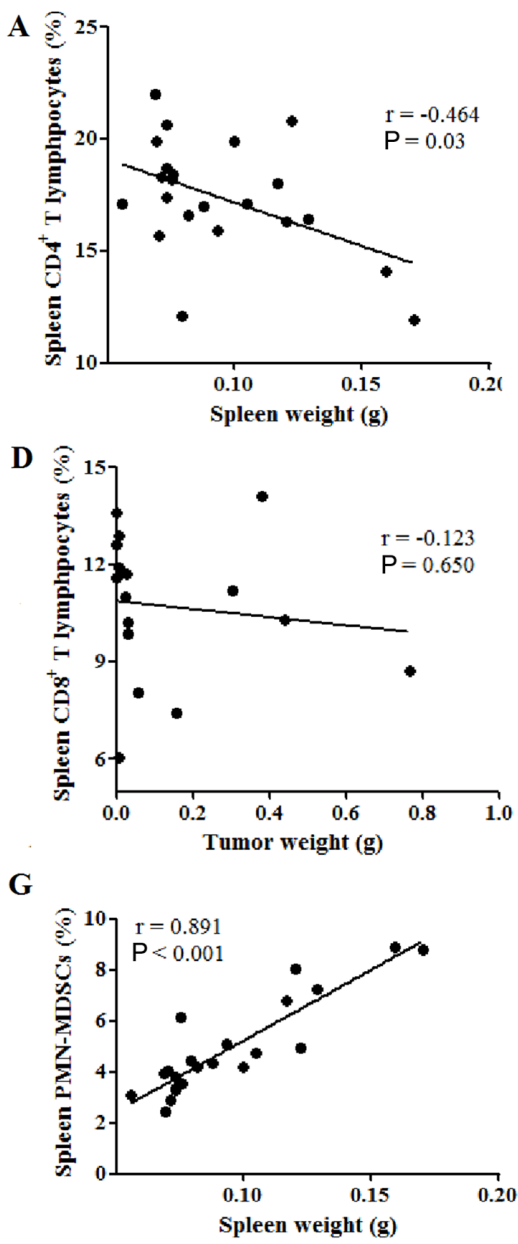

B

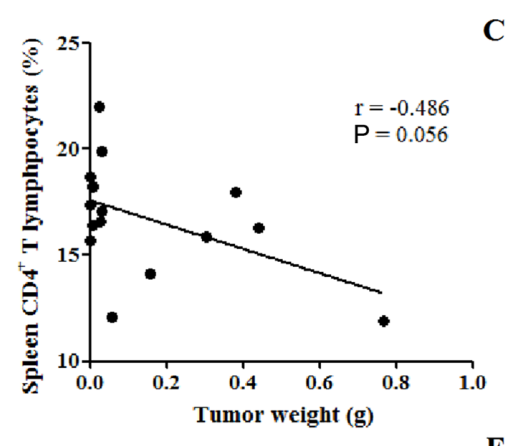

E

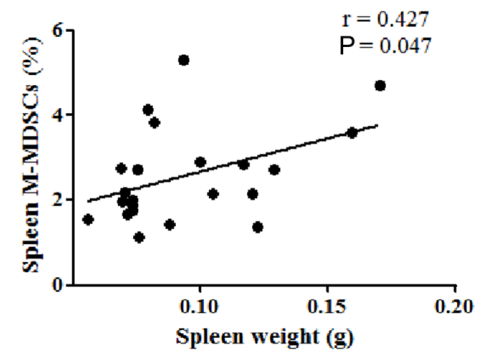

$\mathbf{H}$

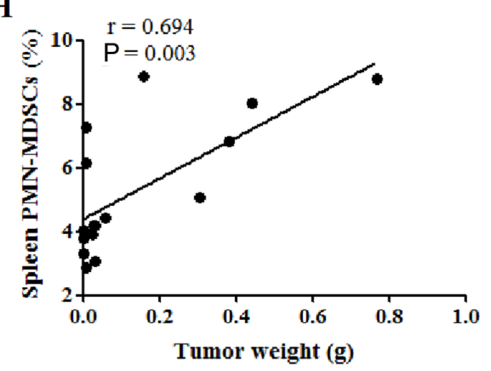

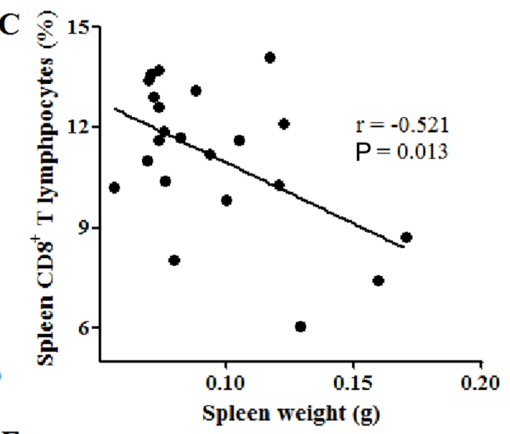

F

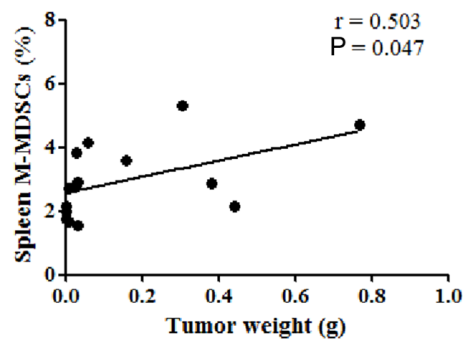

Figure 3. Spleen weight is correlated with the cellular immune response in the spleens of tumor-bearing mice. The percentage of $\mathrm{CD}^{+}{ }^{+} \mathrm{T}$ lymphocytes in the spleen was negatively correlated with (A) spleen weight but not (B) tumor weight. The percentage of CD8 ${ }^{+} \mathrm{T}$ lymphocytes in the spleen was negatively correlated with (C) spleen weight, but not (D) tumor weight. (E) Spleen weight and (F) tumor weight were positively correlated with the percentages of CD11b Ly6 $\mathrm{C}^{\text {hi }}$ Ly $6 \mathrm{G}^{-}$ M-MDSCs in the spleen. (G) Spleen weight and (H) tumor weight were also positively correlated with the percentages of CD11b ${ }^{+}$Ly6C ${ }^{\text {low }}$ Ly6G ${ }^{+}$PMN-MDSCs in the spleen. hi, high; Ly6, lymphocyte antigen 6; M-MDSCs, monocytic-like myeloid-derived suppressor cells; PMN-MDSCs, polymorphonuclear-like myeloid-derived suppressor cells.

percentages of immune cells in the spleen were subsequently investigated. The percentage of $\mathrm{CD}^{+} \mathrm{T}$ lymphocytes was found to be negatively correlated with spleen weight $(\mathrm{P}=0.03$; Fig. 3A), while no correlation was observed between $\mathrm{CD} 4^{+} \mathrm{T}$ cell percentage and tumor weight $(\mathrm{P}=0.056$; Fig. 3B). Similarly, spleen weight was negatively correlated with the percentage of $\mathrm{CD}^{+} \mathrm{T}$ lymphocytes $(\mathrm{P}=0.013$; Fig. 3C), while the tumor weight was not ( $\mathrm{P}=0.650$; Fig. 3D). Furthermore, the spleen and tumor weight were both positively correlated with the percentage of M-MDSCs in the spleen, with Pearson's r values of 0.427 ( $\mathrm{P}=0.047$; Fig. 3E) and 0.503 ( $\mathrm{P}=0.047$; Fig. 3F), respectively. Additionally, both the spleen and tumor weight were positively correlated with the percentage of PMN-MDSCs in the spleen, with Pearson's r values of $0.891(\mathrm{P}<0.001$; Fig. 3G) and 0.694 $(\mathrm{P}=0.003$; Fig. $3 \mathrm{H})$, respectively. These results indicate that spleen weight was negatively correlated with the percentages of tumor-suppressive immune cells, such as $\mathrm{CD}^{+}$ and $\mathrm{CD}^{+} \mathrm{T}$ lymphocytes, while spleen and tumor weight were both positively correlated with the percentages of tumor-promoting immune cells, such as MDSCs, in the spleen of tumor-bearing mice.
Immune cell balance is disrupted in the blood of tumor-bearing mice. Changes in the proportions of immune cells in the peripheral blood of tumor-bearing mice were also investigated, and the results indicated no significant difference in the percentage of $\mathrm{CD}^{+} \mathrm{T}$ lymphocytes $(\mathrm{P}>0.05$; Fig. 4A and $\mathrm{B}$ ) between the tumor-bearing and control mice. The percentages of $\mathrm{CD}^{+} \mathrm{T}$ lymphocytes in the peripheral blood of tumor-bearing mice were decreased at days $7(\mathrm{P}<0.01$; Fig. 4C), 14 ( $\mathrm{P}<0.01$; Fig. 4C) and 21 ( $\mathrm{P}<0.01$; Fig. 4A and $\mathrm{C})$ after tumor cell injection, compared with those in the control group. There were no significant differences in the expression of PD1 on $\mathrm{CD}^{+}{ }^{+} \mathrm{T}$ lymphocyte between tumor-bearing mice and the control mice ( $P>0.05$; Figs. 4D and S2A), while PD1 expression on $\mathrm{CD}^{+} \mathrm{T}$ lymphocytes was increased in tumor-bearing mice at day 21 post-tumor cell injection $(\mathrm{P}<0.05$; Figs. 4E and S2B).

Similarly, the percentage of $\mathrm{CD}_{11 \mathrm{~b}^{+}}$myeloid cells in the peripheral blood of tumor-bearing mice was increased at days 7, 14 and 21 after tumor cell injection, compared with that in the control mice $(\mathrm{P}<0.01$; Figs. $4 \mathrm{~F}$ and $\mathrm{S} 2 \mathrm{C})$. The percentage of $\mathrm{CD} 11 \mathrm{~b}^{+} \mathrm{Ly}_{6 \mathrm{C}} \mathrm{Ly}^{\mathrm{L}} 6 \mathrm{G}^{-} \mathrm{M}-\mathrm{MDSC}$ in the peripheral blood was also higher than that in the control group at day 21 
A

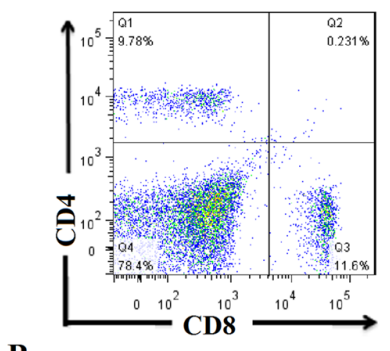

B

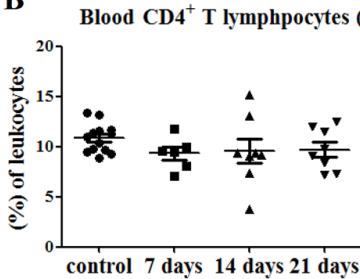

F $\quad$ Blood CD11b ${ }^{+}$myeloid cells (\%)

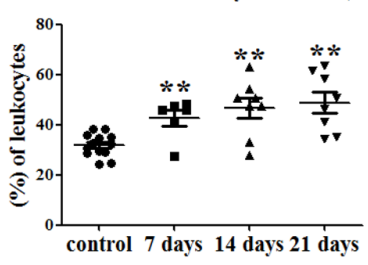

J Blood NK cells (\%)

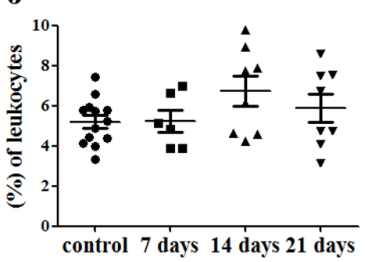

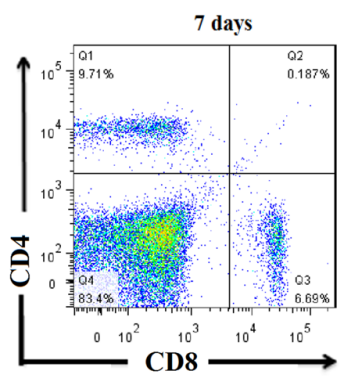

$\mathrm{C}$

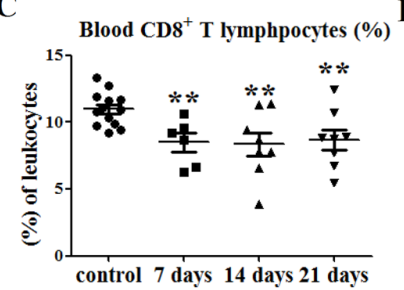

G

Blood M-MDSCs (\%)

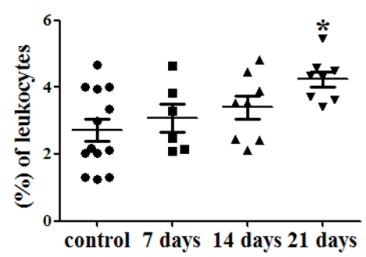

$\mathbf{H}$

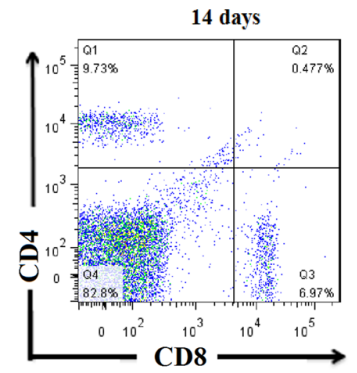

D Blood $\mathrm{CD}^{+} \mathrm{PD1}^{+} \mathrm{T}$ lymphpocytes (\%)
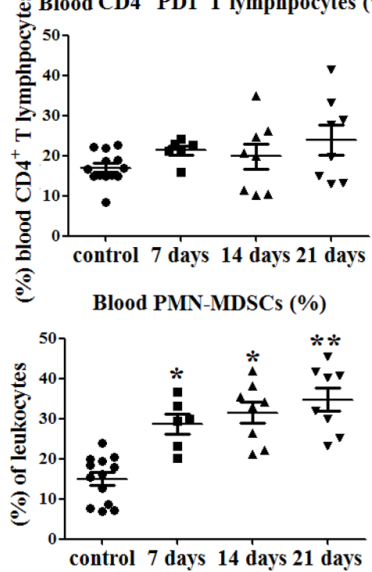

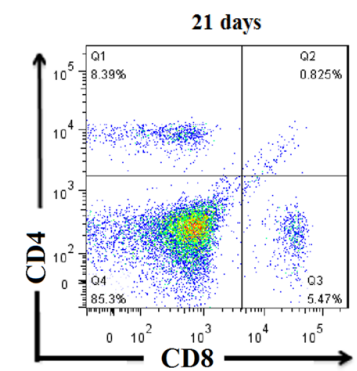

E ${ }^{2}$ Blood CD8 $^{+}$PD1 $^{+}$T lymphpocytes (\%)
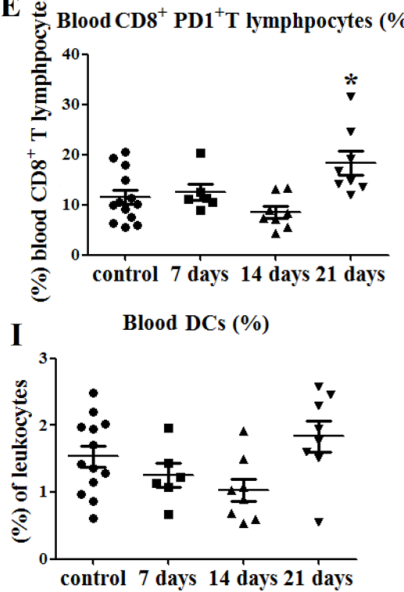

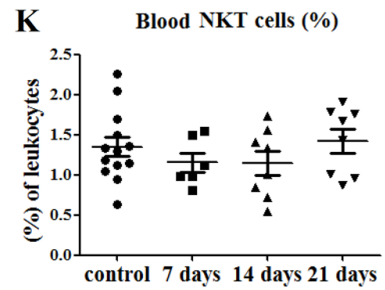

Figure 4. Immune cell balance is disrupted in the blood of tumor-bearing mice. (A) Representative flow cytometry dot plots of blood CD4 ${ }^{+}$and $\mathrm{CD}^{+} \mathrm{T}_{\text {lym- }}$ phocyte levels. (B) No differences in the percentages of blood CD4+ T lymphocytes were observed between tumor-bearing and control mice. (C) Percentages of $\mathrm{CD}^{+} \mathrm{T}$ lymphocytes in the peripheral blood were decreased at days 7, 14 and 21 post-tumor cell injection. (D) No significant differences in PD1 expression on $\mathrm{CD}^{+} \mathrm{T}$ lymphocytes were observed between the tumor-bearing and control mice, (E) while PD1 expression on CD8 ${ }^{+} \mathrm{T}$ lymphocytes was increased at day 21. (F) Percentages of $\mathrm{CD}_{11} \mathrm{~b}^{+}$myeloid cells in the peripheral blood were increased at 7, 14 and 21 days after tumor cell injection. (G) Percentages of peripheral blood

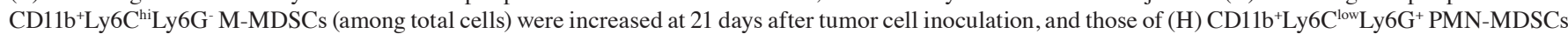
among total cells) were increased at days 7, 14 and 21 . There were no significant differences in the percentages of (I) $\mathrm{CD} 1 \mathrm{c}^{+} \mathrm{MHCII}{ }^{+} \mathrm{DCs},(\mathrm{J}) \mathrm{CD}^{-} \mathrm{NK}^{-} \mathrm{1}^{+} \mathrm{NK}^{-}$ and $(\mathrm{K}) \mathrm{CD}^{+} \mathrm{NK} 1.1^{+} \mathrm{NK}$ T cells in the peripheral blood of tumor-bearing mice compared with control mice. ${ }^{*} \mathrm{P}<0.05$ and ${ }^{* *} \mathrm{P}<0.01 \mathrm{vs}$. control. hi, high; Ly6, lymphocyte antigen 6; NKT, natural killer T; M-MDSCs, monocytic-like myeloid-derived suppressor cells; PMN-MDSCs, polymorphonuclear-like myeloid-derived suppressor cells; DCs, dendritic cells; MHC, major histocompatibility complex; NK1.1, natural killer 1.1; PD1, programmed cell death protein 1.

(P<0.05; Figs. 4G and S2C). Furthermore, the percentages of peripheral blood CD11b+Ly6C ${ }^{\text {low }} \mathrm{Ly}_{6 \mathrm{G}}{ }^{+}$PMN-MDSCs were increased at days 7 ( $\mathrm{P}<0.05$; Figs. $4 \mathrm{H}$ and $\mathrm{S} 2 \mathrm{C}), 14(\mathrm{P}<0.05$; Figs. $4 \mathrm{H}$ and $\mathrm{S} 2 \mathrm{C})$ and $21(\mathrm{P}<0.01$; Figs. $4 \mathrm{H}$ and $\mathrm{S} 2 \mathrm{C})$ in tumor-bearing mice compared with those in control mice. There were no significant differences in the percentages of DCs ( $\mathrm{P}>0.05$; Figs. $4 \mathrm{I}$ and $\mathrm{S} 2 \mathrm{D})$, NK cells $(\mathrm{P}>0.05$; Figs. 4J and S2E) and NKT cells (P>0.05; Figs. 4K and S2E) in the peripheral blood of the tumor-bearing mice compared with the control mice.

These data indicated that the percentages of $\mathrm{CD}^{+}$ $\mathrm{T}$ lymphocytes were decreased, while those of myeloid cells were increased, in the peripheral blood of tumor-bearing mice compared with those in control mice.

Spleen weight is correlated with cellular immune response in the peripheral blood of tumor-bearing mice. Finally, the correlation between spleen or tumor weight and the percentages of immune cells in the peripheral blood was investigated. Neither spleen nor tumor weight were correlated with the percentages of $\mathrm{CD}^{+}(\mathrm{P}>0.05$; Fig. $5 \mathrm{~A}$ and $\mathrm{B})$ and $\mathrm{CD}^{+}(\mathrm{P}>0.05$; Fig. 5C and D) $\mathrm{T}$ lymphocytes in the peripheral blood; however, both were positively correlated with the percentage of M-MDSCs, with Pearson's r values of 0.532 ( $\mathrm{P}=0.011$; Fig. 5E) and $0.621(\mathrm{P}=0.010$; Fig. 5F), respectively. Furthermore, both the spleen and tumor weight were also positively correlated with the percentages of PMN-MDSCs in the peripheral blood, with Pearson's r values of $0.848(\mathrm{P}<0.001$; Fig. $5 \mathrm{G})$ and 0.601 $(\mathrm{P}<0.014$; Fig. 5H), respectively. These results indicated that both the spleen weight and tumor weight were positively correlated with the percentages of MDSCs in the peripheral blood of tumor-bearing mice.

The correlations between the percentages of MDSCs in the spleen and peripheral blood were evaluated following tumor cell inoculation. The percentages of M-MDSCs in the spleen were found to be positively correlated with those of M-MDSCs 


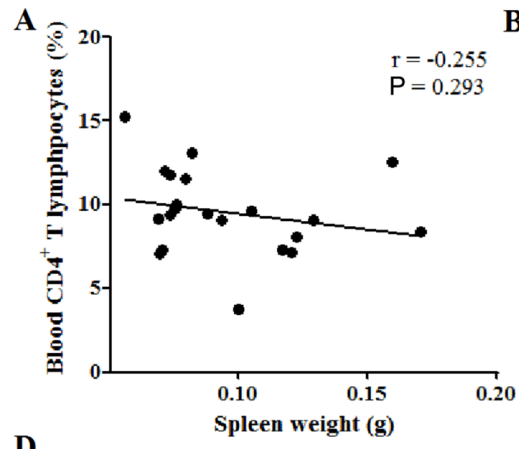

D

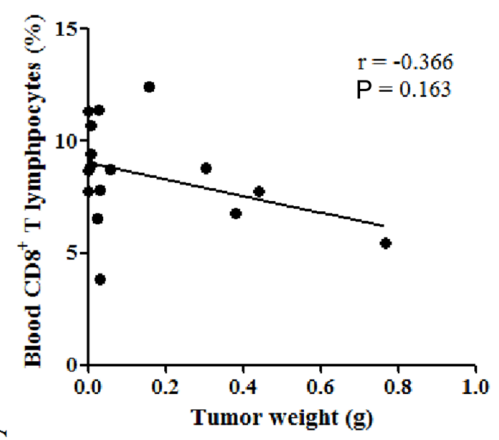

G

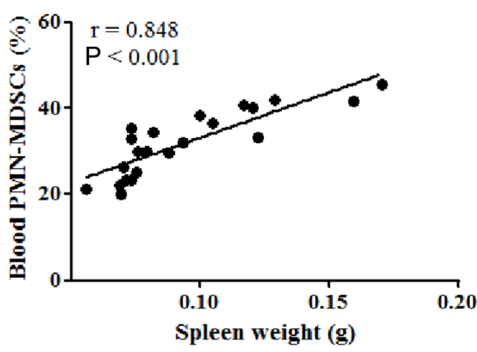

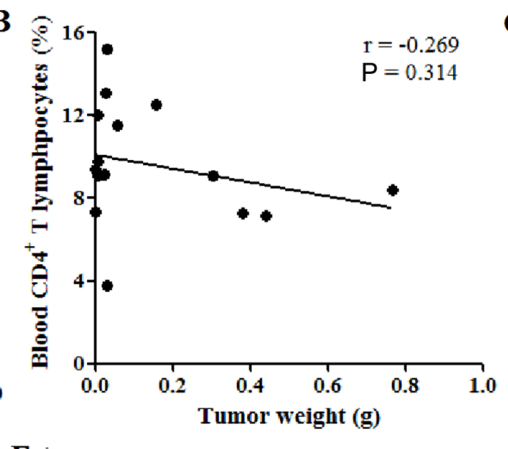

E

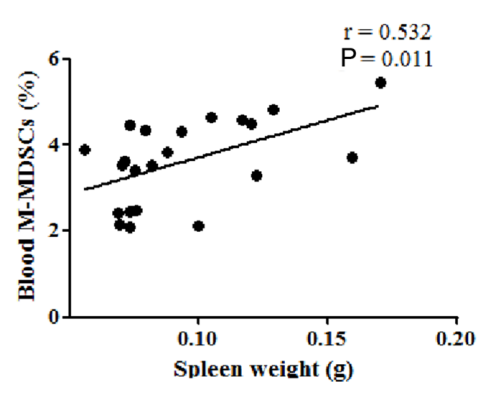

$\mathbf{F}$
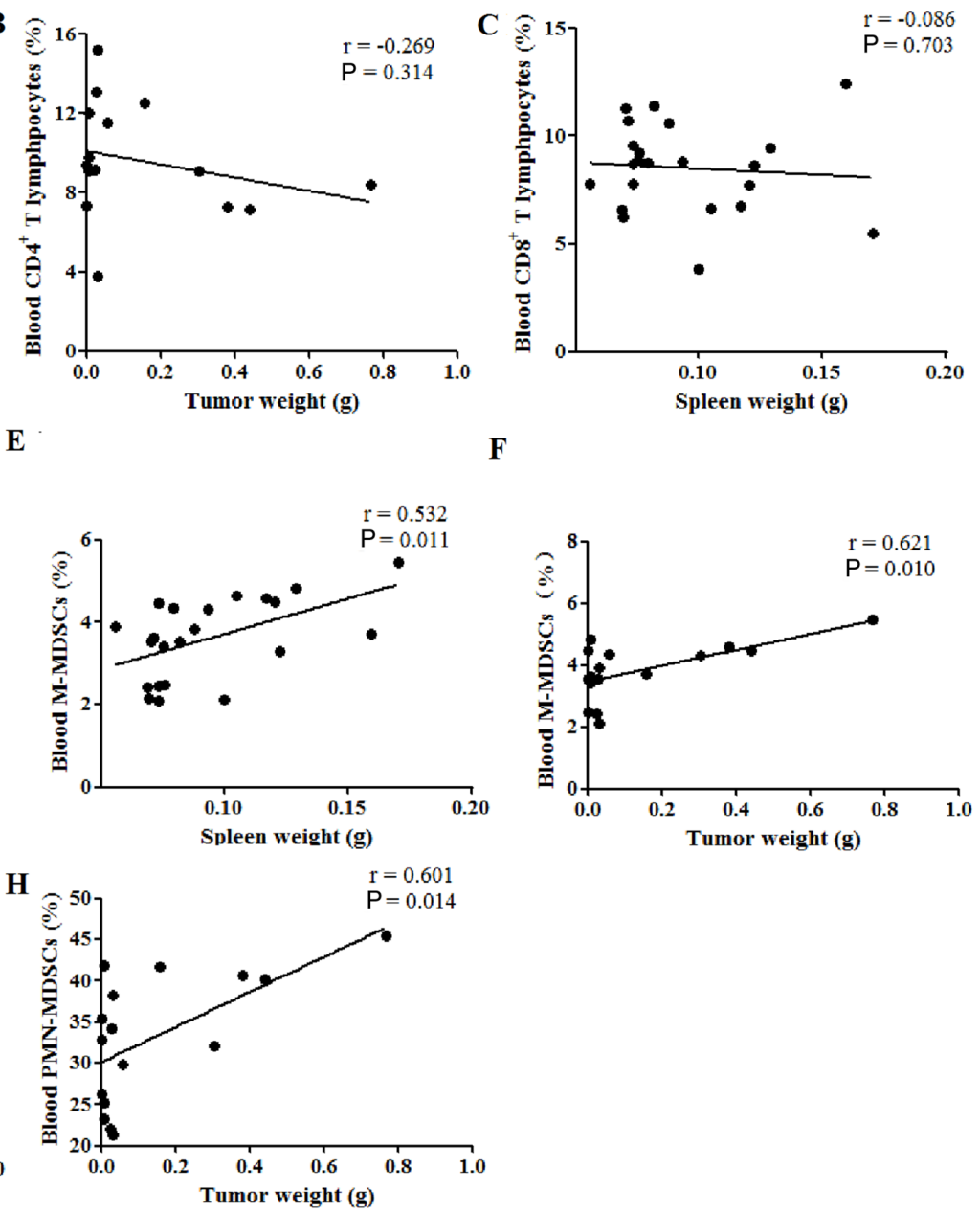

Figure 5. Spleen weight is correlated with the percentages of M-MDSC and PMN-MDSCs in the peripheral blood of tumor-bearing mice. (A) Spleen weight and (B) tumor weight were not correlated with the percentages of CD4 $4^{+} \mathrm{T}$ lymphocytes in the peripheral blood. (C) Spleen weight and (D) tumor weight were also not correlated with the percentages of $\mathrm{CD}^{+} \mathrm{T}$ lymphocytes in the peripheral blood. (E) Spleen weight and (F) tumor weight were positively correlated with the percentages of CD11b ${ }^{+} \mathrm{Ly} 6 \mathrm{C}^{\mathrm{h}} \mathrm{Ly} 6 \mathrm{G}^{-}$M-MDSCs in peripheral blood. $(\mathrm{G})$ Spleen weight and $(\mathrm{H})$ tumor weight were positively correlated with the percentages of CD11b ${ }^{+} \mathrm{Ly} 6 \mathrm{C}^{\mathrm{low}} \mathrm{Ly} 6 \mathrm{G}^{+}$PMN-MDSCs in the peripheral blood. hi, high; Ly6, lymphocyte antigen 6; M-MDSCs, monocytic-like myeloid-derived suppressor cells; PMN-MDSCs, polymorphonuclear-like myeloid-derived suppressor cells.
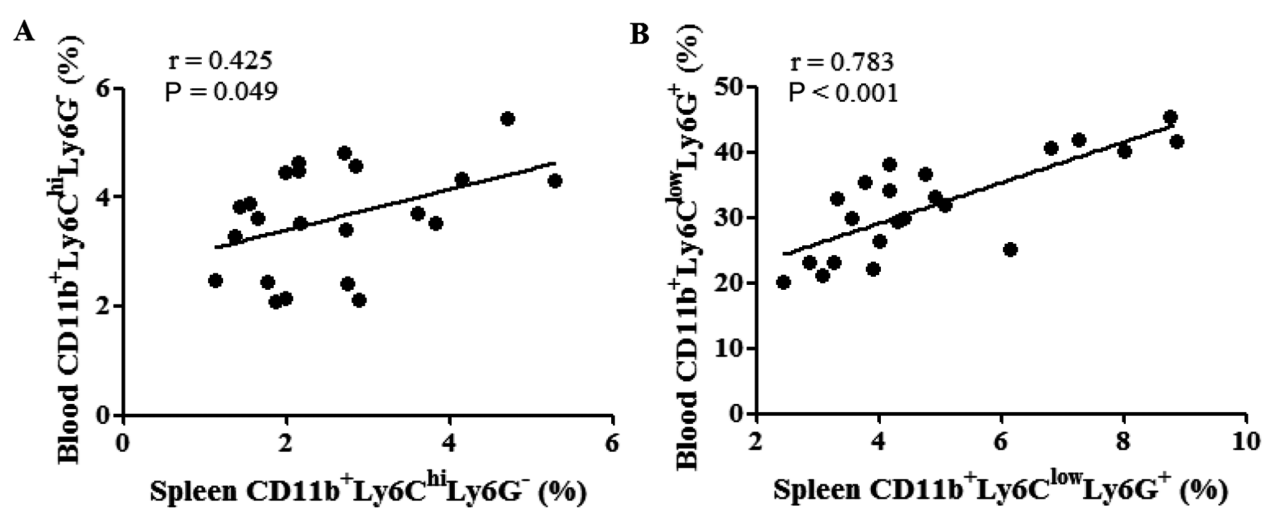

Figure 6. Percentages of MDSCs in the spleen were positively correlated with those of MDSCs in the peripheral blood of tumor-bearing mice. (A) Percentages of M-MDSCs in the spleen were positively correlated with those of M-MDSCs in the peripheral blood. (B) Percentages of PMN-MDSCs in the spleen were also positively correlated with the percentages of PMN-MDSCs in the peripheral blood. hi, high; Ly6, lymphocyte antigen 6; MDSC, myeloid-derived suppressor cell; M-MDSC, monocytic-like MDSC; PMN-MDSC, polymorphonuclear-like MDSC.

in the peripheral blood ( $\mathrm{P}=0.049$; Fig. 6A). Similarly, the percentage of PMN-MDSCs in the spleen was also positively correlated with that of PMN-MDSCs in the peripheral blood $(\mathrm{P}<0.001$; Fig. 6B).

\section{Discussion}

The results of the present study demonstrated a novel role for the spleen in predicting the cellular immune response 
of tumor-bearing mice. Firstly, the spleen weight and SI of tumor-bearing mice at day 21 were increased compared with those of the control group. Secondly, the spleen weight and SI were positively correlated with tumor weight. Thirdly, the percentages of $\mathrm{T}$ lymphocytes were decreased, while those of myeloid cells were increased in the spleen and peripheral blood of tumor-bearing mice at day 21 after tumor cell inoculation. Finally, spleen weight was negatively correlated with the percentages of tumor-suppressive immune cells, such as T lymphocytes, in the spleen, while it was positively correlated with the percentages of tumor-promoting immune cells, such as MDSCs, in the spleen and peripheral blood of tumor-bearing mice.

Although the spleen weight and SI of tumor-bearing mice were revealed to be increased compared with those of the controls, the result was not significant until 21 days after tumor cell inoculation. These findings were consistent with our previous results that spleen weight was observed to increase, and was significantly higher at week 2, in a murine H22 orthotopic hepatoma model (14). Additionally, tumor weight was demonstrated to be positively correlated with both spleen weight and SI. These findings suggested that the spleen may be a suitable marker for cancer diagnosis, as well as a follow-up marker for patients with cancer.

An increasing number of animal studies have demonstrated that the spleen is an important site of extramedullary hematopoiesis and an origin of myeloid cell genesis (22-24). In those with cancer, splenic extramedullary hematopoiesis is generally perceived as a supplementary mechanism to fulfill an increased myeloid cell demand (16), and is characterized by splenic hematopoietic stem/progenitor cells, which are primed and committed to generate immunosuppressive myeloid cells (5). Our previous studies, as well as other previous studies, have indicated that a large number of myeloid cells accumulate in the spleens of tumor-bearing mice $(8,13,14,25)$. Additionally, our previous study has indicated that the immune functions of splenic macrophages are impaired in the advanced stage of cancer (26). The results of the present study suggested that the percentages of T lymphocytes were decreased, while those of myeloid cells were increased in the spleen and peripheral blood of tumor-bearing mice.

MDSCs are a class of immune suppressor cells comprising a heterogenous population of immature granulocytes and monocytes (2,27-29). In mice, MDSCs are defined as $\mathrm{CD}_{11} \mathrm{~b}^{+} \mathrm{Ly}_{6 \mathrm{G}}{ }^{+}$, and numerous studies have further characterized CD11b ${ }^{+}{\text {Ly } 6 C^{\text {hi }}}^{\text {Ly6G }}{ }^{-}$M-MDSC and CD11b ${ }^{+}$Ly6C ${ }^{\text {low }}$ Ly6G $^{+}$ PMN-MDSC subsets $(30,31)$. In tumor tissues, MDSCs differentiate into TAMs or TANs $(6,32)$, and promote tumor progression by suppressing antitumor immunity $(6,33)$. A previous study has also reported that $\mathrm{CD}_{11 \mathrm{~b}^{+} \text {granulocyte }}$ receptor $1^{\text {int }}$ Ly $6 \mathrm{C}^{\text {hi }}$ myeloid cells induce the immunotolerance of memory $\mathrm{CD}^{+} \mathrm{T}$ cells in the spleen (1). A recent study revealed that tumor tissues were heavily infiltrated by MDSCs with the ability to inhibit cytotoxic T cell expansion (34). The results of the present study indicated that the percentages of CD11b ${ }^{+}$Ly6G-Ly6C ${ }^{\text {hi }}$ PMN-MDSCs increased at days 7, 14 and 21 and $\mathrm{CD} 11 \mathrm{~b}^{+} \mathrm{Ly} 6 \mathrm{C}^{\mathrm{hi}} \mathrm{Ly} \mathrm{G}^{-} \mathrm{M}-\mathrm{MDSC}$ increased at day 21 post-tumor cell administration. Notably, PD1 expression on $\mathrm{CD}^{+} \mathrm{T}$ lymphocytes in the peripheral blood of tumor-bearing mice was also increased at day 21 , indicating that the mice were immunosuppressed.
Spleen volume can be determined by computed tomography or magnetic resonance imaging, which may be used as a predictor of disease. For example, patients with primary myelofibrosis and a low spleen volume experience improved leukemia-free survival and overall survival times compared with those with a high spleen volume (35). Post-stroke infections, as well as a decrease in lymphocytes and various lymphocyte subsets, are associated with a reduction in spleen volume following acute ischemic stroke (36). Notably, spleen size may also be a predictor of tumor prognosis. A recent study indicated that a larger spleen volume is a predictor of hepatocellular carcinoma occurrence and poor overall survival rates in patients with compensated chronic liver disease resulting from chronic hepatitis B infection (37). In patients with hepatocellular carcinoma, a larger spleen volume is associated with a higher rate of liver failure and worse overall survival rates after hepatectomy (38), and spleen volumetry has been considered to be a predictor of persistent post-hepatectomy decompensation in patients with hepatocellular carcinoma (39). Furthermore, a previous study indicated that spleen length and stiffness are predictors for the development of hepatocellular carcinoma (40). A decrease in spleen volume has been observed in patients with locally advanced non-small cell lung cancer receiving chemo-radiotherapy (17).

The spleen is an origin of MDSC genesis and tumor immune tolerance $(1,16)$. In patients with hepatocellular carcinoma, splenectomy combined with hepatectomy positively influences the recovery of T-lymphocyte subsets and the maintenance of the T helper (Th)1/Th2 cytokine balance (41). The results of the present study revealed that spleen weight was negatively correlated with the percentages of tumor-suppressive immune cells, such as $\mathrm{CD}^{+}$and $\mathrm{CD} 8^{+} \mathrm{T}$ lymphocytes, in the spleen, but positively correlated with the percentages of tumor-promoting immune cells, such as M-MDSC and PMN-MDSC, in the spleen and peripheral blood of tumor-bearing mice. To the best of our knowledge, the present study was the first to investigate whether spleen weight was a predictor of the cellular immune response in tumor-bearing mice. Therefore, the present results require verification in further studies of patients with cancer. In future clinical research, more attention should be paid to the association between spleen volume and the immune status and prognosis of patients with tumors.

In conclusion, spleen weight may be a predictor for tumor prognosis, since it is directly correlated with tumor weight and the percentages of M-MDSC and PMN-MDSCs in tumor-bearing mice.

\section{Acknowledgements}

Not applicable.

\section{Funding}

The present study was supported by the Natural Science Foundation of Shaanxi Province (grant no. 2021JQ-410), the National Natural Science Foundation of China (grant no. 91842307), the Youth Science Foundation of the Second Affiliated Hospital of Xi'an Jiaotong University [grant no. YJ (QN) 2018.07], and the Program for Changjiang Scholars and Innovative Research Team in University (grant no. IRT1171). 


\section{Availability of data and materials}

All data generated or analyzed during this study are included in this published article.

\section{Authors' contributions}

WJ and ZL conceived and designed the experiments. WJ and YL conducted the animal studies. WJ, GK and YL conducted the flow cytometric analysis. WJ and SZ analyzed the data. WJ, GK and ZL wrote the manuscript. WJ and GK modified the manuscript. WJ and ZL confirm the authenticity of all the raw data. All authors read and approved the final manuscript.

\section{Ethics approval and consent to participate}

The present study was approved by the Ethics Committee of Xi'an Jiaotong University College of Medicine (Xi'an, China).

\section{Patient consent for publication}

Not applicable.

\section{Competing interests}

The authors declare that they have no competing interests.

\section{References}

1. Ugel S, Peranzoni E, Desantis G, Chioda M, Walter S, Weinschenk T, Ochando JC, Cabrelle A, Mandruzzato S and Bronte V: Immune tolerance to tumor antigens occurs in a specialized environment of the spleen. Cell Rep 2: 628-639, 2012.

2. Marvel D and Gabrilovich DI: Myeloid-derived suppressor cells in the tumor microenvironment: Expect the unexpected. J Clin Invest 125: 3356-3364, 2015.

3. Jiang W, Li Y, Wei W, Li JW, Li L, Zhang C, Zhang SQ, Kong GY and Li ZF: Spleen contributes to restraint stress induced hepatocellular carcinoma progression. Int Immunopharmacol 83: 106420, 2020.

4. Xia Y, Wei Y, Li Z-Y, Cai XY, Zhang LL, Dong XR, Zhang S, Zhang RG, Meng R, Zhu F, et al: Catecholamines contribute to the neovascularization of lung cancer via tumor-associated macrophages. Brain Behav Immun 81: 111-121, 2019.

5. Wu C, Ning H, Liu M, Lin J, Luo S, Zhu W, Xu J, Wu WC, Liang J, Shao CK, et al: Spleen mediates a distinct hematopoietic progenitor response supporting tumor-promoting myelopoiesis. J Clin Invest 128: 3425-3438, 2018.

6. Kumar V, Patel S, Tcyganov E and Gabrilovich DI: The nature of myeloid-derived suppressor cells in the tumor microenvironment. Trends Immunol 37: 208-220, 2016.

7. Cortez-Retamozo V, Etzrodt M, Newton A, Rauch PJ, Chudnovskiy A, Berger C, Ryan RJ, Iwamoto Y, Marinelli B, Gorbatov R, et al: Origins of tumor-associated macrophages and neutrophils. Proc Natl Acad Sci USA 109: 2491-2496, 2012.

8. Cortez-Retamozo V, Etzrodt M, Newton A, Ryan R, Pucci F, Sio SW, Kuswanto W, Rauch PJ, Chudnovskiy A, Iwamoto Y, et al: Angiotensin II drives the production of tumor-promoting macrophages. Immunity 38: 296-308, 2013.

9. Han Y, Liu Q, Hou J, Gu Y, Zhang Y, Chen Z, Fan J, Zhou W, Qiu S, Zhang Y, et al: Tumor-Induced Generation of Splenic Erythroblast-like Ter-Cells Promotes Tumor Progression. Cell 173: 634-648.e12, 2018.

10. Kristinsson SY, Gridley G, Hoover RN, Check D and Landgren O: Long-term risks after splenectomy among 8,149 cancer-free American veterans: A cohort study with up to 27 years follow-up. Haematologica 99: 392-398, 2014.

11. Lv X, Yang F, Guo X, Yang T, Zhou T, Dong X, Long Y, Xiao D and Chen Y: Hypersplenism is correlated with increased risk of hepatocellular carcinoma in patients with post-hepatitis cirrhosis. Tumour Biol 37: 8889-8900, 2016.
12. Dubeykovskaya Z, Si Y, Chen X, Worthley DL, Renz BW, Urbanska AM, Hayakawa Y, Xu T, Westphalen CB, Dubeykovskiy A, et al: Neural innervation stimulates splenic TFF2 to arrest myeloid cell expansion and cancer. Nat Commun 7: 10517, 2016.

13. Li B, Zhang S, Huang N, Chen H, Wang P, Yang J and Li Z: CCL9/CCR1 induces myeloid derived suppressor cell recruitment to the spleen in a murine $\mathrm{H} 22$ orthotopic hepatoma model. Oncol Rep 41: 608-618, 2019.

14. Li B, Zhang S, Huang N, Chen H, Wang P, Li J, Pu Y, Yang J and Li Z: Dynamics of the spleen and its significance in a murine H22 orthotopic hepatoma model. Exp Biol Med (Maywood) 241: 863-872, 2016.

15. Miller MR, Mandell JB, Beatty KM, Harvey SA, Rizzo MJ, Previte DM, Thorne SH and McKenna KC: Splenectomy promotes indirect elimination of intraocular tumors by $\mathrm{CD} 8^{+}$ $\mathrm{T}$ cells that is associated with IFN $\gamma$ - and Fas/FasL-dependent activation of intratumoral macrophages. Cancer Immunol Res 2: 1175-1185, 2014

16. Bronte V and Pittet MJ: The spleen in local and systemic regulation of immunity. Immunity 39: 806-818, 2013.

17. Wen SW, Everitt SJ, Bedő J, Chabrot M, Ball DL, Solomon B, MacManus M, Hicks RJ, Möller A and Leimgruber A: Spleen volume variation in patients with locally advanced non-small cell lung cancer receiving platinum-based chemo-radiotherapy. PLoS One 10: e0142608, 2015.

18. Jiang W, Li Y, Li ZZ, Sun J, Li JW, Wei W, Li L, Zhang C, Huang C, Yang SY, et al: Chronic restraint stress promotes hepatocellular carcinoma growth by mobilizing splenic myeloid cells through activating $\beta$-adrenergic signaling. Brain Behav Immun 80: 825-838, 2019.

19. Jiang W, Li Y, Sun J, Li L, Li JW, Zhang C, Huang C, Yang J, Kong GY and Li ZF: Spleen contributes to restraint stress induced changes in blood leukocytes distribution. Sci Rep 7: 6501, 2017.

20. Li Y, Jiang W, Li ZZ, Zhang C, Huang C, Yang J, Kong GY and Li ZF: Repetitive restraint stress changes spleen immune cell subsets through glucocorticoid receptor or $\beta$-adrenergic receptor in a stage dependent manner. Biochem Biophys Res Commun 495: 1108-1114, 2018.

21. Gabrilovich DI: Myeloid-derived suppressor sells. Cancer Immunol Res 5: 3-8, 2017.

22. Li L, Duan M, Chen W, Jiang A, Li X, Yang J and Li Z: The spleen in liver cirrhosis: Revisiting an old enemy with novel targets. J Transl Med 15: 111, 2017.

23. McKim DB, Patterson JM, Wohleb ES, Jarrett BL, Reader BF, Godbout JP and Sheridan JF: Sympathetic release of splenic monocytes promotes recurring anxiety following repeated social defeat. Biol Psychiatry 79: 803-813, 2016.

24. Swirski FK, Nahrendorf M, Etzrodt M, Wildgruber M, Cortez-Retamozo V, Panizzi P, Figueiredo JL, Kohler RH, Chudnovskiy A, Waterman P, et al: Identification of splenic reservoir monocytes and their deployment to inflammatory sites. Science 325: 612-616, 2009.

25. Jordan KR, Kapoor P, Spongberg E, Tobin RP, Gao D, Borges VF and McCarter MD: Immunosuppressive myeloid-derived suppressor cells are increased in splenocytes from cancer patients. Cancer Immunol Immunother 66: 503-513, 2017.

26. Zhang S, Li ZF, Pan D, Huang C, Zhou R and Liu ZW: Changes of splenic macrophage during the process of liver cancer induced by diethylnitrosamine in rats. Chin Med J (Engl) 122: 3043-3047, 2009.

27. Mundy-Bosse BL, Thornton LM, Yang HC, Andersen BL and Carson WE: Psychological stress is associated with altered levels of myeloid-derived suppressor cells in breast cancer patients. Cell Immunol 270: 80-87, 2011.

28. Wang H, Zou C, Zhao W, Yu Y, Cui Y, Zhang H, e F, Qiu Z, Zou $\mathrm{C}$ and Gao X: Juglone eliminates MDSCs accumulation and enhances antitumor immunity. Int Immunopharmacol 73: 118-127, 2019.

29. Zheng R, Chen S and Chen S: Correlation between myeloidderived suppressor cells and S100A8/A9 in tumor and autoimmune diseases. Int Immunopharmacol 29: 919-925, 2015.

30. Mohammadpour H, MacDonald CR, Qiao G, Chen M, Dong B, Hylander BL, McCarthy PL, Abrams SI and Repasky EA: $\beta 2$ adrenergic receptor-mediated signaling regulates the immunosuppressive potential of myeloid-derived suppressor cells. J Clin Invest 129: 5537-5552, 2019.

31. Geng J, Yuan Y, Jiao X, Wang R, Liu N, Chen H, Griffin N and Shan F: Novel modulation on myeloid-derived suppressor cells (MDSCs) by methionine encephalin (MENK). Int Immunopharmacol 68: 193-203, 2019. 
32. Ostrand-Rosenberg S: Myeloid derived-suppressor cells: Their role in cancer and obesity. Curr Opin Immunol 51: 68-75, 2018.

33. Ma M, Huang W and Kong D: IL-17 inhibits the accumulation of myeloid-derived suppressor cells in breast cancer via activating STAT3. Int Immunopharmacol 59: 148-156, 2018.

34. Jiang K, Li J, Zhang J, Wang L, Zhang Q, Ge J, Guo Y, Wang B, Huang Y, Yang T, et al: SDF-1/CXCR4 axis facilitates myeloid-derived suppressor cells accumulation in osteosarcoma microenvironment and blunts the response to anti-PD-1 therapy. Int Immunopharmacol 75: 105818, 2019.

35. Song MK, Chung JS, Lim SN, Lee GW, Lee SM, Lee NK, Choi JC and Oh SY: Usefulness of spleen volume measured by computed tomography for predicting clinical outcome in primary myelofibrosis. Int J Hematol 104: 476-484, 2016.

36. Nous A, Peeters I, Nieboer K, Vanbinst AM, De Keyser J and De Raedt S: Post-stroke infections associated with spleen volume reduction: A pilot study. PLoS One 15: e0232497, 2020.

37. Yoo J, Kim SW, Lee DH, Bae JS and Cho EJ: Prognostic role of spleen volume measurement using computed tomography in patients with compensated chronic liver disease from hepatitis B viral infection. Eur Radiol 31: 1432-1442, 2020.
38. Bae JS, Lee DH, Yoo J, Yi NJ, Lee KW, Suh KS, Kim H and Lee KB: Association between spleen volume and the post-hepatectomy liver failure and overall survival of patients with hepatocellular carcinoma after resection. Eur Radiol 31: 2461-2471, 2021.

39. Fernández-Placencia R, Golse N, Cano L, Allard MA, Pittau G, Ciacio O, Cunha AS, Castaing D, Salloum C, Azoulay D, et al: Spleen volumetry and liver transient elastography: Predictors of persistent posthepatectomy decompensation in patients with hepatocellular carcinoma. Surgery 168: 17-24, 2020.

40. Marasco G, Colecchia A, Colli A, Ravaioli F, Casazza G, Reggiani ML, Cucchetti A, Cescon M and Festi D: Role of liver and spleen stiffness in predicting the recurrence of hepatocellular carcinoma after resection. J Hepatol 70: 440-448, 2019.

41. Cao ZX, Chen XP and Wu ZD: Effects of splenectomy in patients with cirrhosis undergoing hepatic resection for hepatocellular carcinoma. World J Gastroenterol 9: 2460-2463, 2003.

(i) (9) $($ This work is licensed under a Creative Commons

EY NG ND Attribution-NonCommercial-NoDerivatives 4.0 International (CC BY-NC-ND 4.0) License. 